\title{
ナノ精度マイクロ機械加工の現状と将来* \\ Future Technologies of Nano-Precision Micro/Meso Mechanical Manufacturing
}

\author{
㕌川常元** \\ Tsunemoto KURIYAGAWA
}

\section{1.はじめに}

21 世紀は高齢化社会といわれており，安心かつ安全で 質の高い生活を実現するためのデバイスやシステムへの要 求が高まりつつある。このようなデバイスがますます複雑 化，微細化していくことは必至であり，これらを製造する ための“ものづくり”技術も高度化していかなければなら ない.そのためには, NT (Nano-Technology), IT (Information Technology), BT (Bio-Technology), MT (Manufacturing Technology) 等の基盤技術を根本から究 明し，有機的に融合することが重要になるであろう。今 後, MT 分野のフロンティアを目指し, ナノ精度マイクロ 機械加工技術 (Nano-Precision Micro/Meso Mechanical Manufacturing: $\mathrm{M}^{4}$ process）の新しい加工原理の創出と, その科学的解明ならびに実用化を視野に入れた研究が重要 視されてくるものと考えられる.

\section{2. ナノ精度機械加工技術}

\section{1 次世代非球面光学素子の新加工法一超安定 - 超精 密非球面研削一}

光デジタル機器や光情報通信機器, 内視鏡などの高度医 療機器のキーパーツである非球面レンズゃミラーには，さ らなる高精度, 高精細, 高信頼性が強く求められている. 本研究の目的は, 現在, 国内の非球面レンズの主流を占め ている樹脂製非球面レンズをガラスに置き換えるととも に，いまだ解決されていない加工形状誤差の摇らぎ発生を 抑制することにより，現状の非球面ガラスレンズの形状精 度を飛躍的に高める手法と加工システムを開発することで ある。これまで開発してきた，形状精度を向上させること のできる円弧包絡研削法, 仕上げ面粗さを向上させること のできるパラレル研削法, 研削鏡面のナノトポグラフィー 創成機構シミュレーションなどのシーズを基盤として，世 界で初めて超安定・超精密非球面研削加工システムの開発 を行った．このシステムを用いることにより，ガラス製非 球面レンズならびにガラスプレス用超硬金型の超精密研削

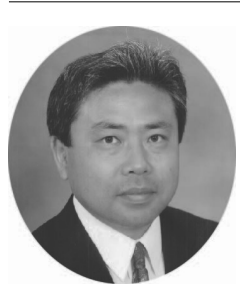

*原稿受付 平成 20 年 10 月 24 日

*正 会員 東北大学大学院工学研究科 (仙台市 青葉区荒巻字青葉 6-6-01)

厨川常元

1987 年 3 月東北大学大学院工学研究科（精密工 学専攻) 博士課程修了. 1992 年東北大学助教授 工学部. 2003 年東北大学教授大学院工学研究 科. 専門分野はナノ精度機械加工, M4 プロセ ス, パウダージェット加工.
加工に成功した. その結果, 非球面の加工精度が飛躍的に 向上し（形状精度 $\pm 25 \mathrm{~nm}$, 表面粗さ $18 \mathrm{nmRy}$ ), その加 工表面に形状誤差パターンがないガラス製非球面光学素子 が研磨レスで得られるようになった。

\section{2 半導体・光学結晶のナノ表面および新機能創成一 硬脆材料の超精密延性モード切削加工一}

半導体や光学結晶 $\left(\mathrm{Si}, \mathrm{Ge}, \mathrm{CaF}_{2}\right)$, ガラス等の硬脆材料 であっても一定の条件を満たせば金属切削と同様に延性モ ード加工が可能である。すでに単結晶ダイヤモンドバイト を用いて半導体基板や非球面レンズ・フレネルレンズ, 自 由曲面および微細溝を短時間で超精密加工する技術が開発 されている. 本加工技術は赤外線光学系の小型化 ·高機能 化, 大型液晶ディスプレーの高画質化などに大きく貢献す るものと考えられる. さらに, ナノインデンテーション法 やレーザラマン分光法などを用いて加工変質層 (Subsurface Damage) の評価を行い, ナノレベルの加工 における微視的な材料変形・破壊・相転移機構を解明する とともに，全く新しい表面機能の創成を目指している.

\section{3. マイクロ機械加工（ $\mathrm{M}^{4}$ プロセス）技術}

近年, マイクロレンズアレイ, ホログラム光学素子, 光 導波路などのように，シリコン以外の材料からなるマイク ロ部品のニーズが高まってきている。これらの大きさは 1 $\mathrm{mm}$ 以下のいわゆるサブミリサイズのものもあり, 形状も 複雑である. しかも材料自体も高硬度, 高脆性, 高融点の ものが多いため, 前述したようなリソグラフィ技術はもち ろん, レーザ, 電子ビームなどの熱的加工が不向きで, そ の加工は特に難しい. また加工能率, 加工コストの点から も，低コストな高能率微細加工法が望まれている。しかし このような 10 ミクロンからサブミリサイズの加工技術に 関してはいまだ確立されておらず，将来の技術確立へ向 け, 極めて重要な研究領域であると考える. 機械的な方法 でこのようなマイクロ加工を行うマイクロ機械加工（ $\mathrm{M}^{4}$ プロセス）の新しい加工原理の開発が行われている.

3.1 マイクロパーツの超精密・超平滑加工一電気粘性 流体援用マイクロ非球面研磨一

これまで非球面の研磨加工は，もっぱら熟練者によるハ ンドポリッシング，あるいは小さな研磨パッドを NCで走 査させることにより行われていた。しかしマイクロ非球面 の場合は，小さな研磨パッドを作製すること自体難しく， 加工域を微小領域に限定することも困難である. また遊離 砥粒加工において加工能率を高めるためには, 多くの砥粒 をいかに研磨領域に確保し, その状態を長く維持するかが 

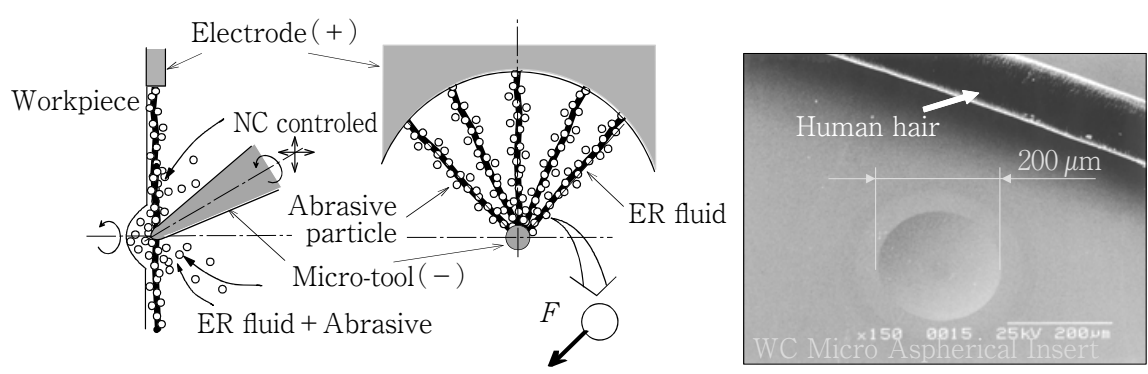

（a）電気粘性流体援用研磨原理図

（b）超硬合金製マイクロ非球面金型

図 1 電気粘性流体援用マイクロ非球面研磨法概略
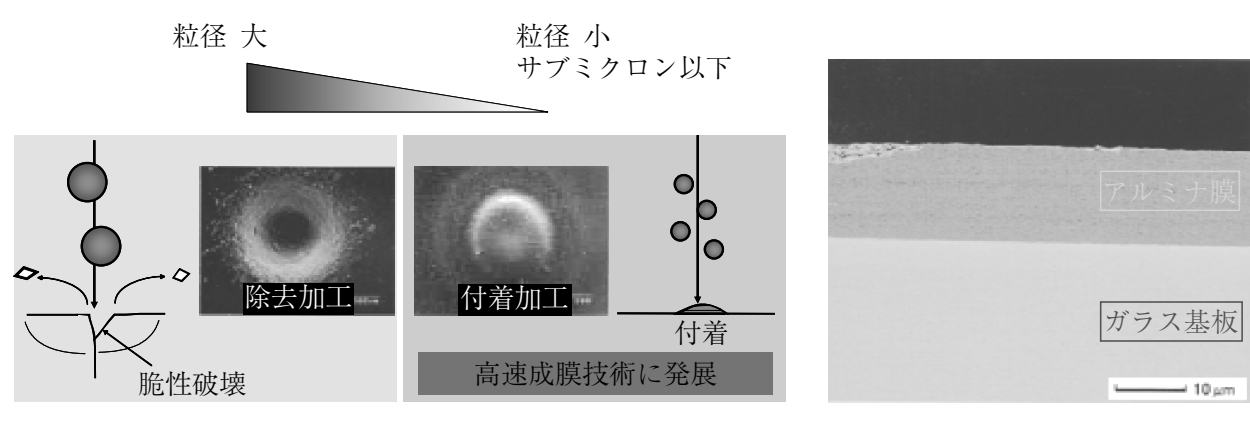

（a）除去から付着現象への遷移

（b）ガラス板の上に成膜されたアルミナ厚膜

図 2 パウダージェットデポジション

重要な因子となるが, マイクロ非球面の場合には工具と工 作物の界面に砥粒を密に集中させることが困難になる.

そこで電界の強さに比例して粘度が増加する電気粘性流 体（ER 流体）を援用することにより研磨砥粒を極微小領 域に集中させ，研磨する方法が開発されている。その結 果, これまで全く行うことができなかったマイクロ非球面 の研磨加工が可能となった（図 1 参照).

\section{2 微細穴, 微細溝加工一電気粘性流体援用マイクロ 超音波加工一}

超音波砥粒加工により，ガラスやセラミックス等の硬脆 材料に対しサブミリサイズ（10〜数 $100 \mu \mathrm{m} ）$ の微小穴, 微細溝, 3 次元微小構造体を形成するためのマイクロ超音 波加工システムが開発されている。前述の電気粘性流体援 用法を採用することにより，多くの砥粒を保持することが できるようになり，高品位な加工形状が得られるようにな った。

\section{4. パーティクルジェット加エ}

サンドブラストなどの噴射加工はこれまで精密加工法と いう範疇では捉えてこられなかった。 しかし, 微粒子の精 密分級分散技術, 精密定量供給技術ならびに噴射技術を開 発することにより，精密除去加工法の一つとして実用化さ れるようになっている。 また近年では，図 2 (a) に示す ように噴射粒子を小径化することにより，その粒子材料を 付着させるエアロゾルデポジション法やパウダージェット デポジション法など厚膜形成法が開発されている。このよ うにパーティクルジェット技術は精密除去加工のみなら ず, 付着加工への応用展開, さらには医療やバイオ等の異
分野への広範囲な応用が期待されている.

\section{1 パウダージェットデポジション一常温大気圧環境 下での高速付着加工一}

高精度に微粒子を噴射し, 成膜することのできるデジタ ル式パウダージェットデポジション装置が開発され, 室 温, 大気圧環境下で種々の材料（ガラス，セラミックス， 半導体材料, 金属材料, ダイヤモンド, プラスチック等) を付着させることが可能になった。本技術は，常温成形 · 集積化を低コストで可能にするもので，絶縁膜や誘電膜， 2 次電池用厚膜, 表面改質膜等の新機能複合材料の創成に およぶ広範囲な応用展開が期待されている（図 2 参照）.

\section{2 未来の歯科治療を目指して一生体・バイオマテリ アル高機能インターフェースの創成一}

微粒子噴射による付着現象を利用して, 室温, 大気圧環 境下でハイドロキシアパタイト（HA）微粒子を, ヒトの 歯の表面（エナメル質）に高速で衝突させることにより， $\mathrm{HA}$ 厚膜を成膜することも可能になっている。本手法は, 新しい歯質の再構築を可能にするもので, 虫歯治療や予防 歯科の分野において, 従来の歯科治療を根本から変える技 術として注目されている。

\section{5. 今後に期待するもの}

これまでの機械加工はいかに高精度な形状を創成するか ということのみに注力してきた。しかし今後はこの“形状 創成”に，その加工表面上に何らかの機能を発現する構造 (例えば，サブミクロンオーダの周期構造等）を創成する “機能性インターフェース創成”を加味する加工法が提案 され，実用化されるものと考える。 